\title{
Do really the Audience's Views Efficiently Boost Built Heritage Conservation Policies?
}

\author{
By Mohammed Jasim* \\ Laura Hanks ${ }^{\dagger}$ \\ Katharina Borsi ${ }^{+}$
}

\begin{abstract}
The role of the audience in re-manufacturing built heritage sites and formulating their conservation policies has often been outlawed by the full control of the site authority through its singularity in formulating these policies. Excluding the locals from efficient participation in setting up these policies is usually attributed by the authority to the vague role that they would precisely play. However, the rich body of ICOMOS Charters and UNESCO Conventions has frequently considered the locals as "real custodians" of these sites, legitimising their participation in drawing up heritage conservation policies. This is due to the diverse cultural potential that can be made by them for the conservation policies of these sites. This paper investigates the precise role that the audience can demonstrate within re-manufacturing heritage and constructing its futuristic policies. It is indicated that the audience's views possess different motives culturally, historically and touristically that enable them to efficiently participate in re-manufacturing the architectural heritage of their traditional environments. Therefore, the public's deep experience towards their heritage issues can revive the site with some practical ideas stemming from its reality.
\end{abstract}

Keywords: local participation, built heritage conservation policy-making, heritage cultural values, decentralising power, ICOMOS Charters

\section{Introduction}

Built heritage sites grant significance for the place where they existed (Dicks 2000, 2003). This significance prioritises the heritage industry to be more vital and more present. However, many challenges often emerge while optimising heritage conservation policies, specifically within how to construct heritage decisions of re-manufacturing its past. One of the most notable challenges among them is the task of decision-making process. Two main powers often act as a key decision maker in drawing the site policies, which are either the authority of the site or its locals (IUCN 2004, Carlsson and Berkes 2005). Meanwhile, the role of the latter has often been deactivated and outlawed by the full control of the former through its singularity in structuring these policies. Excluding the locals from efficient participation in constructing built heritage policies is usually attributed to concerns over the vague role that they would precisely

\footnotetext{
* Researcher of Architecture, University of Nottingham, UK.

${ }^{\dagger}$ Associate Professor and Senior Tutor, Department of Architecture and Built Environment, Faculty of Engineering, the University of Nottingham, UK.

+ Assistant Professor, Department of Architecture and Built Environment, Faculty of Engineering, the University of Nottingham, UK.
} 
play. Concisely, their hardness in accepting some modernist concepts and techniques in re-presenting heritage values may signify an impasse on decisionmaking process (Aas et al. 2005, Su and Li 2012).

Nevertheless, the locals have frequently been emphasised as real "custodians" of built heritage sites by different ICOMOS charters and UNESCO conventions to share the task of decision-making of conservation policyformulation alongside with the site authorities (ICOMOS 1999, 2013b). Legitimising this emphasis is perhaps due to the fact that they possess diverse knowledge regarding the cultural values, social traditions and historical events of these sites (Dicks 2000, Timothy and Boyd 2003). The paper endeavours to explore the importance of breaking the rule of top-down decision-making and involving the local views in crystallising more thorough decisions regarding heritage conservation policies. As a methodology, this paper relies on a qualitative analytical approach, which draws upon a two-folded point. Firstly, it investigates key literature to concisely recapitulate the global emphasis on the necessity of involving the local communities of built heritage sites in planning for their "homes". Secondly, it reviews relevant studies in this respect that enable suggesting, or at least discuss, new approaches of conservation policy-making that guarantee efficient participation for those views on the grassroots level of the site through a process of decentralised mechanism. To achieve this, firstly, the paper narrates some local and global experiences that either show the positive role of the local community involvement in some successful examples or indicate the reasons behind impeding such involvement in other processes, which entails the impacts of the top-down approach on conservation decisionmaking. Secondly, it reviews the effect of the role of the inhabitants in formulating heritage conservation policies related to cultural heritage values and their touristic objectives, as two essential goals for many world heritage sites currently. The paper concludes with some fundamental factors that support its debate.

\section{The Role of Local Community in Formulating Heritage Conservation Policies}

\section{First: Within the Treatises of Heritage Specialists}

A heritage conservation process is considered by the American Institute for Conservation 'AIC' in (1996) as: 'the profession devoted to the preservation of cultural property for the future' (p. 1). Vinas (2005) states that the contemporary theory of conservation aims at involving 'diverse, as often as fragmented, sources who go beyond the universe of [conservation...to] engage on a profound and coherent analysis of the ideas' (as cited in Hidaka 2008: 6), thus attempting to include different locals' ideas from and around the site. De Guichen questions the limited contribution made by some conservatory specialists to 'the protection of our heritage' and he points out that there is a delicate gap between them and the process of conservation itself (Vinas 2005: 142). Therefore, the need is to ensure wide participation of views, which contribute to broadening the mechanism and objectives of conservation, in reference to the importance of involving the 
local community in such processes. Crooke (2007) demonstrates the local community's role as a substantial factor embedded in the heritage expansion throughout history that enables the vernacular heritage actions of individuals to conserve and present some cultural features associated with the local history of the site. Wan (2004) and Jiang (2006) reveal that despite the diverse cultural and tourist potentials of built heritage, many challenges emerge during the elaboration of thorough plans for the site and the optimisation of its conservation policies. Accordingly, local participation in constructing these policies is usually considered as a significant theme for resolving such challenges due to the inhabitants' rich knowledge of their local environments including their cultural traditions and social habits. Hence, their experience enables tackling such local themes, reviving these policies with practical ideas stemming from the reality of the heritage.

In this respect, Lowenthal (1985) argues that if real appreciation of a heritage site is premised on the values attached to the site that nurture its vitality, the conservation policies should highly consider the locals' experiences and coexistence with that site. Some bygone cultural information of heritage is inherent in the local social repercussions entangled with the site as an essential key whereby the individual and collective memory is inseparable or correlative. Therefore, the defiance is not "when" and "where" in the heritage chronology that this information would be objectively analysed, but identifying a specific involvement of the popular elite in order to achieve the objectivity of the analysis. According to Taylor (2004) and Silva and Chapagain (2013), the locals who share a mutual sense of heritage and are consequently able to emphasise the heritage spirit are the popular elite who should know more about their heritage and its traditions, meanings and values. In this regard, Jackson (1983) and Taylor (2004) indicate that some of the heritage cultural meanings are strongly embraced by, and linked to the locals' cultural values and their social traditions. Thus, it is crucial to call for the involvement of the locals in drawing up future policies for these sites; those locals are truly "akin" to and "built-in" the site's significance and meanings.

With regard to the potential role of the local stakeholders, Zhang (2006) and Huang (2006) point out that their participation resuscitates the totalitarian image of the requirements of the site through the growing improvements of their local life criteria as a reflection of heritage development. To ensure integrated policies, vast participation of the stakeholders can assist in formulating new guides with regard to the site's continuous changes so as to prove the vitality of the conservation policies over time and keep them able to respond to any future changes. Nevertheless, a wide range of literature, such as Tunbridge and Ashworth (1996), Feilden (1998), and Poria and Biran (2006), has pointed out that there is still an absence in the local stakeholders' actual engagement in how to balance conservation objectives in some global archaeological and heritage environments.

Based on Hall (1999, 2000), Roberts and Simpson (1999), Castro and Nielsen (2001), and Aas et al. (2005), due to their far-reaching theses, stimulating the local stakeholders' participation can enrich the conservation policies of dynamic 
intents and more coherent goals. Furthermore, their mutual interests and attitudes regarding the process of patronising heritage's diverse potentials undoubtedly facilitate establishing an applicable and collaborative mechanism. Through opening conservation policies towards involving more opinions from such sites, experienced people can reinforce awareness and self-reliance of them as well as enlarging their consensus and responsibility towards these mutual historical properties. Nuryanti (1996) and Hall and McArthur (1998) argue that the concept of involving the stakeholders recently became more significant, particularly for those who are custodians of the site. Their participation can increase the level of interaction to its extreme, thereby reducing different cultural problems of patrimony. Similarly, Wager (1995), Thapa (2007) and Nicholas (2009) affirm that incorporating locals' views as well as actual collaboration with the principal stakeholders is crucial to ensuring long-term heritage policies. In conclusion, endorsing local residents and stakeholders' views about conservation policies is increasingly viewed as fundamental to the sustainability and integrity of built heritage.

\section{Secondly: Within UNESCO and ICOMOS Charters}

Many of the ICOMOS Charters urge robust local participation in sustaining the various dimensions of built heritage sites, as they have established strong relationships with their legacy through embracing the local traditions and norms in conjunction with these environments. The Venice Charter (1964), for instance, reminds of the necessity in valorising the locals' awareness of heritage values when conserving built heritage as those 'people are becoming more...conscious of the unity of human values and regard ancient monuments as a common heritage' (p. 1). The Burra Charter (1999) opposes the underestimation of the locals' views when it comes to the historical chronology of the heritage and its events, since the growth of heritage awareness among the local people is attributed to the local values that those people have experienced through the site events over time. The locals are more informative about their heritage and its culture as they are regarded as experts of the physical features of the heritage and its meanings. Their consciousness is therefore comprehensive, and enables them to reveal the site's diverse values through their mutual relations with it that demonstrate the sensation and belonging of the place. Consequently, the Charter stresses 'the participation of people for whom the [site] has special associations and meanings, or who have social, spiritual or other responsibilities' for the site, namely the locals (p. 5).

In addition, the ICOMOS Charter for Managing Tourism at Places of Cultural Heritage Significance (2002) compiles the basic procedures that must be involved in setting out the conservation policy, setting the role of the indigenous people in the fore. It states that indigenous peoples should be involved in planning for conservation' of their homes (Principle 4: 11). The Principles for the Conservation of Heritage Sites of ICOMOS (2004) also give a priority to the local role of both authority and audience in deriving their own local legislation and capitalising from the international methodologies of 
protecting the built heritage. The findings of this Charter show that the success of some of heritage conservation policies in China holds a strong connection between the site and the inhabitants as an interrelated element in the site's history and culture. This robust link significantly assisted in assimilating the sound comprehension towards the past, and then, to be a base for the site's future planning. These motives, for the Quebec ICOMOS (2008), support involving the inhabitants of the site in preserving the built heritage as "the spirit of the place":

Given that local communities are generally in the best position to comprehend the spirit of [built heritage], especially in the case of traditional cultural groups, we maintain that they are also best equipped to safeguard it and should be intimately associated in all endeavours to preserve and transmit the spirit of [the site] (ICOMOS 2008: 4).

Another attempt of the Australia ICOMOS Charter (2013a), which is a revision of the 'Burra Charter' (1999), calls for more local guidelines for the heritage conservation rather than the universality of the Burra guidelines, prioritising the local participatory role. The Charter quotes the Burra principles of (1999) and repeatedly underlines the priority that should be 'provide[d] for the participation of people for whom the place has significant associations and meanings, or who have social, spiritual or other cultural responsibilities for the place' (Article 12: Participation, p. 5). Furthermore, the second attempt of the Australia Burra Charter (2013b) also highlights that the knowledge and expertise of indigenous peoples should be considered and well thought-out, and thus:

It is critical that assessments of cultural significance for indigenous heritage places reflect the views and input of the relevant indigenous knowledgeholders. Indigenous people are the relevant knowledge-holders for [built heritage] of indigenous cultural significance. Their traditional knowledge and experience must be appropriately used and valued in the assessment of [these] places (p. 3).

The Burra Charter of the Australia ICOMOS (2013a) defines conservation as 'all the processes of looking after a [historical] place so as to retain its cultural significance'; the latter should reflect 'a range of values for different individuals' of the site, linking it with them (p. 2). The Charter determines policies of cultural heritage conservation that should consider "the owners' needs" of the site (p. 4). "Article 29" puts explicit emphasis on the "responsibility" of the individuals in accordance with the decisions of the built heritage. Their responsibilities 'should be named...for each decision' (p. 9).

The contribution here might represent by the new criteria that appropriate the local practice of conserving the significance of heritage sites through the potential role for the local people to be engaged in preserving their heritage. The local community is able to propose advice, participate in the decisions, and 
perform the conservation process in the site of cultural significance through teams including managers, owners, stakeholders and the inhabitants. This Convention clarifies the role of the locals through utilising the term "place", which involves diverse matters, including the local views and social effectiveness with their interrelated cultural traditions that together lead the heritage preservation works to accomplish their results. Consequently, it emphasises the necessity of local involvement in heritage conservation processes from the base to the top of formulation and implementation of the heritage conservation policies that are clearly cited in the general process of the Burra Charter (Figure 1).

Figure 1. Community Involvement in Understanding Heritage Significance and Developing its Conservation Policies According to 'The Burra Charter Process'

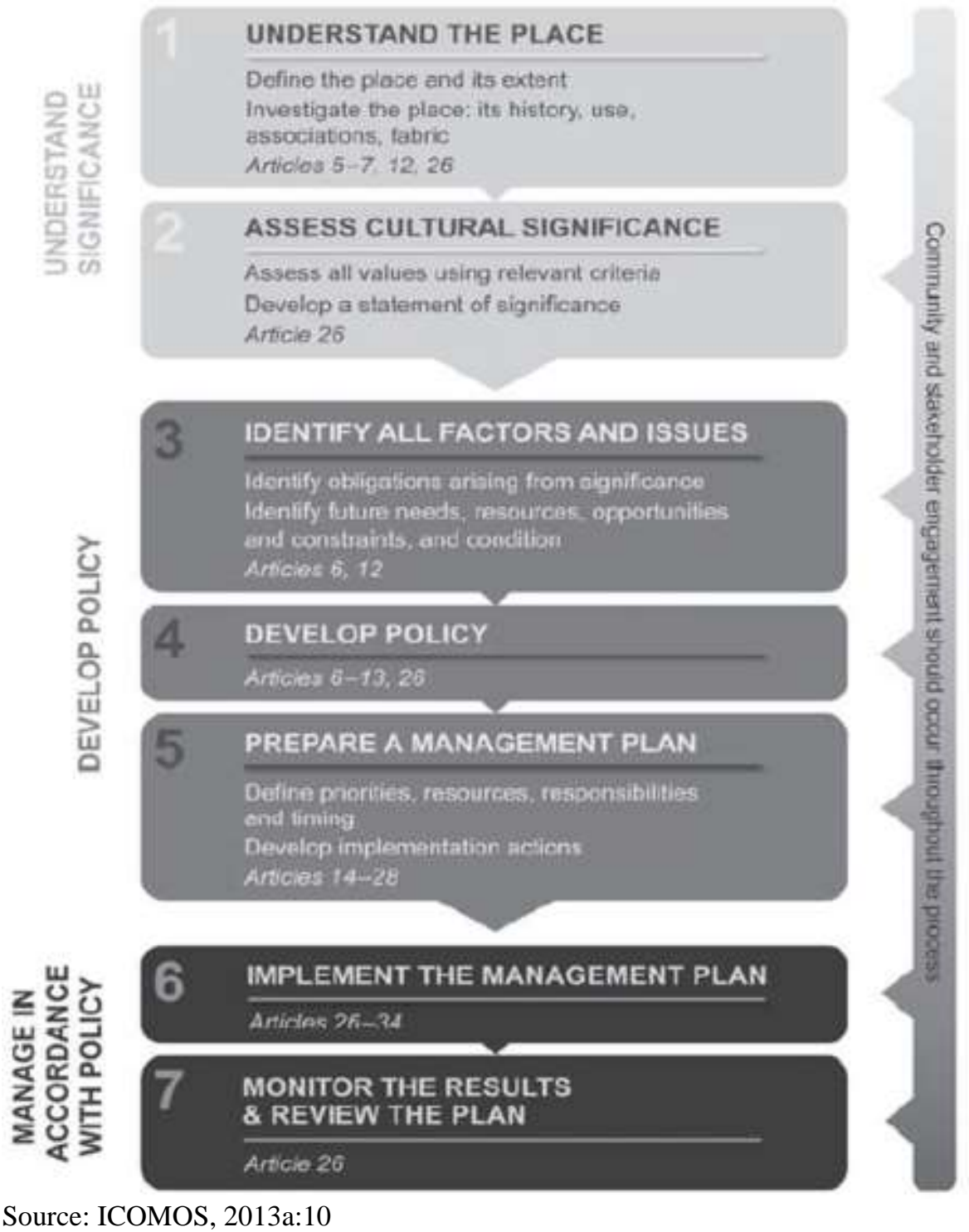

In this respect, the World Conservation Union 'IUCN' (1996, 2000, and 2004) recommends a dynamic and 'effective participation of local communities... 
in establishing and reviewing...protected areas policy' (IUCN 2004: 6). The IUCN counsels that the locals' contribution should be a part of every action of heritage protection and encouraged 'to debate their environmental priorities and to develop local strategies. [The authority] should then help the community to convert their strategies into action' (IUCN 2004: 10). Accordingly, achieving successful conservation policy-making, the inhabitants should be engaged in deciding on the site's diverse issues. A collective right should be set that guarantees the locals' seniority, which grants them the precedence in maintaining their own cultural and urban heritage.

Table 1. The Reference to The Locals' Participatory Role in Drawing Up Heritage Conservation Policies in the ICOMOS Charters and the IUCN

\begin{tabular}{|c|c|c|}
\hline No. & Title of the Charter & Reference to Local Participation \\
\hline 1 & $\begin{array}{l}\text { ICOMOS (1964): } \\
\text { Venice Charter }\end{array}$ & $\begin{array}{l}\text { Through emphasising the locals' awareness of the site's local } \\
\text { culture, social dimensions and local traditions }\end{array}$ \\
\hline 2 & $\begin{array}{l}\text { ICOMOS (1999): } \\
\text { Burra Charter }\end{array}$ & $\begin{array}{l}\text { Through emphasising the link between the locals and the site's } \\
\text { cultural values }\end{array}$ \\
\hline 3 & $\begin{array}{l}\text { ICOMOS (2002): } \\
\text { Principles and } \\
\text { Guidelines }\end{array}$ & $\begin{array}{l}\text { Through exalting a general reference to the locals' position in } \\
\text { setting out the heritage site's conservation policy }\end{array}$ \\
\hline 4 & $\begin{array}{l}\text { ICOMOS (2004): } \\
\text { Getty Institute }\end{array}$ & $\begin{array}{l}\text { Through the priority given to the site's local authorities and } \\
\text { inhabitants in deriving a particular approach in dealing with } \\
\text { the specific site }\end{array}$ \\
\hline 5 & $\begin{array}{l}\text { ICOMOS (2008): } \\
\text { Quebec } \\
\text { Declaration }\end{array}$ & $\begin{array}{l}\text { Through the locals' ability in revealing the site's bygone } \\
\text { history }\end{array}$ \\
\hline 6 & $\begin{array}{l}\text { ICOMOS (2013): } \\
\text { Australia Charter }\end{array}$ & $\begin{array}{l}\text { Through the reference to the locality of the heritage rather } \\
\text { than the universality of the international guidelines }\end{array}$ \\
\hline 7 & $\begin{array}{l}\text { IUCN }(1991,2000 \\
\& 2004)\end{array}$ & $\begin{array}{l}\text { Through the recommendation of effective participation of the } \\
\text { locals in drawing up the site's conservation policies }\end{array}$ \\
\hline
\end{tabular}

Source: The Researcher

The World Conservation Union (2004) indicates that the residents can contribute to some real consultations regarding the decisions and objectives of built heritage, which facilitate valid cultural information about the site. This necessitates empowering the inhabitants in dynamic engagement of assessing some relevant issues inherently associated with their mutual relationship with the site. Additionally, creating a state of conjugation between those inhabitants and the site experts so as to delicately distil the cultural knowledge rooted in this relation (Table 1). Thus, the role of locals' participation is powerfully endorsed globally as if it was an "imposition" on the local community of the site. Beltran (2000) and Kerr (2013), attribute that to the fact that the indigenous and the site are inextricably tied to each other culturally due to their long-term cohabitation, which consequently acts as a mutual identity between them.

\section{Evidence on the Positive Role of Locals' Participation}

Central to the above international heritage charters, some global instances can show the dynamic local participation in the formulation of heritage policies, 
which reflect some fruitful results for the site. These examples provide lessons about the positive outcomes that can be achieved through the active engagement of local community in making heritage decisions. They refer to genuine experience that should provide inspiration for any future conservation process on built heritage. In particular, those instances hold tourist, historical and cultural aims as an overall objective, which corresponds to the goals behind most of the conservation processes of built heritage sites currently.

For instance, a study on Borobudur site considers tourism as a 'vital tool for economic growth specifically [for] the authorities' (Hampton 2005: 743). Here, the political power has directed the site to serve some global tourist purposes, which were subsequently interpreted locally as a kind of globalising the site's traditionalism. In return, the locals submitted an alternative proposal, showing more respect of the genius loci of the site to be used as a means of tourism attractions instead of implanting "Java World" (series of modern shopping malls) adjacent to the ancient site, which subsequently gained high consideration by the site authority. In fact, such a contribution by the locals has prevented the site from being directed by "the "one size fits all" strategy drawn by site decision-makers (Hampton 2005: 754). This entails giving up the mono focus on the concept of "the bigger mindset is better" in generating more viable ideas (reference to the top-down vision of decision-making processes). This might not always be a wise trend towards the tourist approach particularly when it necessitates detecting some traditional cultures that are rooted in the place. In such cases, the mindset of experts needs to be intermingled with the local traditional experience of the inhabitants.

In line with this, the study of Nicholas (2009) on the "Residents' Perspectives of a World Heritage Site" on PMA shapes the next piece of evidence for the positive impact of local participation in constructing heritage future policy. ${ }^{1}$ It shows that 'despite their lack of involvement', the more views from the indigenous inhabitants, 'the more supportive they will be of the PMA as a world heritage site and [its] Sustainable Tourism Development' (Nicholas 2009: 405). Perhaps this is attributed to the significant level of cultural attachment of those indigenous with the place, which granted them more confidence to be rightful decisionmakers 'over their own resources and livelihood infrastructure' (Cochrane and Tapper 2006: 101).

Likewise, Wager (1995) demonstrates that the participation of the locals in planning for the Angkor World Heritage Site, in northern Cambodia, has vitally assisted in building a broad understanding and further awareness towards protecting the surrounding urban landscape of the site. Additionally, it integrates its global tourist aims into the urban economy of the place through the exploitation of the notion of the buffer zone surrounding the site. Conversely, the study of Aas et al. (2005) on "Stakeholder Collaboration and Heritage Management" reveals that one of the setbacks of Luang Prabang Heritage Site in Laos was attributed to the shy engagement of the locals in a real decision-making process, which

\footnotetext{
${ }^{1}$ PMA refers to the Pitons Management Area as a World Heritage Site. The study of Nicholas et al (2009) has examined the locals' influence on the sustainable tourism development of the site through synthesis of factors.
} 
limited their capabilities in the participation in active negotiations. The study indicates that 'involving the local community in decision- making' processes of this site should have been considered as a key issue in heritage conservation (Aas et al. 2005: 28). The local power approach of Luang Prabang as a centralised authority was identified as the main impediment, which was "not to be conducive to stakeholder collaboration' (Aas et al. 2005: 43). Henceforth, "'manipulation" and "therapy" [in the] ladder of citizen participation should serve as warnings against involving the local community in decision-making at a superficial or manipulative level (Aas et al. 2005: 43). Otherwise, it exacerbates the case of deadlock in achieving the goals of the site policies.

Accordingly, the global emphasis on the locals' role in drawing up heritage conservation policies can be summarised as follows:

A. Involving the locals in demonstrating the historical chronology of the site and its archaic values and cultural traditions.

B. Granting them an opportunity to formulate an informative base regarding the heritage physical features and their diverse meanings.

C. Prioritising the deep-rooted cohabitation between the residents and their homes being more facilitative and enriching for the site's policies analysis.

D. Granting factual participation for the local community in distilling the heritage significance, culturally and historically due to being pertinent, integral and realistic component to the site.

E. Aligning the locals' role with the authorities' role in drawing up the conservation processes to be considered one of two powers that would construct specific basics for the heritage policies.

In fact, this constant emphasis on the essentiality of offering heritage sites' local communities a real opportunity to planning for the future of these sites urges debating their specific role in demonstrating heritage cultural values and supporting its tourist goals, as the future aims of most of these sites are a purely tourist destination. This is grounded on their rich cultural values, which form the backbone for their conservation policies.

\section{The Role of Local Community in Demonstrating Heritage Cultural Values and Consolidating Conservation Tourist Objectives}

Linking the cultural values to the heritage significance, Dicks (2000, 2003) states that the present heritage significance represents the "in-betweenness" case between the past and the present. Therefore, the notion of the "living history" as a present heritage is usually attributed to the narrating stories with unflagging gusto of the local communities that increase the significance of the built heritage. This can indicate a clear engagement between the individuals who share mutual memories of the site and the heritage of the site, rooted in their structures as deep cultural values. Hence, their diverse views towards the heritage values can hold manifold facts that contribute to broadening its 
significance, since heritage is a means of demonstrating the past, memories, and locality of the site community. Consequently, the locals' narrations formulate a concrete base of fostering its meanings that can assist in evaluating heritage, which is far from being a tool that trivialises these values, as some believe. Chapman (2008) and Casey (2007) demonstrate the reason beyond that the local communities of a specific heritage site are interlinked as a part of a heritage network as a power inherently entrenched in the site throughout its history. Therefore, they can participate in reducing some passive impacts that result from the confusion in investigating heritage structure as history for a site, and instead, understand heritage as a social and cultural process to grasp and interact with the present.

Feilden (1998), Dicks (2000), and Nicholas (2009) state that the idea of heritage cultural values started to formulate a substantial role in promoting the sustainable development of the heritage site. Consequently, engaging the inhabitants in demonstrating plethora of these values particularly those forgotten cultural values of the site should be prioritised, which perhaps assists in drawing up clear-cut policies. In addition, involving the locals in such a process would contribute in avoiding any possible deterioration or misuse of these values (UNESCO 2005). Owing to the significant role for the inhabitants in comprehending the site's outstanding values, a sort of collective agreement among them on the priority of these values should be established when making decisions for the site (Blandford 2007). This consequently allows for scaling, comprehending and prioritising the site's requirements.

According to Taylor (2004) and McKercher et al. (2005), currently, there is affirmation of the attraction of cultural heritage sites for fuelling tourist industries in our present-day built environment. Therefore, cultural heritage is evoked at different levels to motivate the economic purposes, particularly the tourism sector. Besides expediting the continuous detection of heritage values, numerous factors stand behind activating such tourist policies, and most of these factors can be supported by the role of the local communities, which often originates from, and is inherent to the built heritage. MacDonald and Jolliffe (2003), state that the local community's role is 'very effective' in boosting such purposes and can be demonstrated as 'community-based partnerships' ( $p$. 307). They assist in establishing 'long-term growth for cultural...tourism strategies' as 'key informants play varied and often overlapped roles' to manifest the tourist destinations of their patrimony (MacDonald and Jolliffe 2003: 309).

Concurrently, those local communities who are ignored in participating in heritage manufacturing are less supportive for the site development, as 'they have no "heritage stake" in it', which would reduce its values' revelation (Uriely et al. 2003: 73). Therefore, understanding heritage diverse historical values and events and being strongly coexistent with the local communities enables more understanding of the site's characteristics. Evidence for this comes from Poria et al. (2003) who elucidate that global visitors 'who viewed the [site] as bound up with their own heritage are likely to behave significantly differently from others' (p. 238), referring to the mutual cultural dialogue that can be drawn from both the site and its residents due to the shared cultural language between 
them. Besides, the local communities' views can be redirected towards a deep investigation regarding the passive impact of inscribing these sites upon the World Heritage List 'WHL' (Huang et al. 2012), such as the possible deterioration results from unscheduled visits. Therefore, the 'WHL' should incorporate the local community views as a traditional local mechanism, considering them as 'the custodians of many World Heritage sites' (UNESCO 2013). Their incorporation is supportive in placing appropriately the site's tourist potentials within the global tourism market. Moreover, it helps at tying up the site to its local setting, which prevents any possible concern from globalising its culture and traditions in the long run.

In this regards, based on Byrd (2007), some heritage tourism studies set a direct positive correlation between the locals' participation and formulating productive policies for the site for multiple reasons. Firstly, it reduces potential conflicts to a minimum. Secondly, active local participation proposes new applicable ideas for management of the economic development, future protection of the site and refining some local inspirations and suggestions during heritage manufacture (Joppe 1996, Timothy 1999, Mitchell and Reid 2001, Timothy and Boyd 2003). This makes local participation essential in making conservation policies, whereby setting heritage tourism goals 'would be integrated in the social fabric of the destination' (Nicholas 2009: 397). Moreover, Aas et al. (2005) argue that involving the local community in the conservation's decisionmaking process builds a 'more satisfactory and harmonious relationship between heritage conservation and tourism' (p. 37). Indeed, these vital turns have shifted the current studies to place concrete emphasis on the role of local participation equally with the site authorities in the industry of heritage tourism.

Hence, whereas the engagement of the bottom-up views should be activated to the limit, these views often suffer from a state of underestimation when it comes to decision-making process of conservation policies, which might require more debate.

\section{The Obstacle to the Locals' Views from Efficient Participation in Conservation Policy-making}

With the insistence of some decision-makers to possess the master role of controlling heritage conservation policy-formulation, some weaknesses have surfaced, making this top-down approach subject to debate. Whereas, it is seen by many that it leads to some delicate policies, this master role is also argued that it impedes the policy continuity, deviating it from achieving its goals (Hidaka 2008). This, on the one side, makes the need for an actual engagement of the local community in constructing conservation policies is crucial. On the other hand, it requires further discussion regarding the exact reasons that prevent these policies achieving their gaols.

Based on Jenkins-Smith and Sabatier (1993), following the top-down approach in policy-making, the conservation policy formulation mostly suffers from fragilities for multiple reasons, such as deficiency of flexibility in its self- 
evaluation, the imprecision of describing its objectives, and the impractical technique of resolving the site issues. It is therefore considered as a onedirection-decision-making process, or, the policy of authority. Practically, it stumbles in accomplishing its objectives, as it is incapable of accounting for the feedback loop being a one-direction process. This results in rigorous controls upon the conservation policies that often lead to a self-evaluation of the conservation process by the site's decision-makers and a weak role of local participation in structuring these policies. These indicators may compose the key points beyond some contradictions between the power and the local community, which ultimately influence the optimal planning for the future of the site's cultural values.

A revision of Hidaka (2008) on the "Contemporary Theory of Conservation" has revealed an intrinsic point in this respect when demonstrates that tying the mission of conservation to an array of specialists only would obscure some subtle issues within the entire site. In many cases, the detection of these issues does not require some contemporary techniques, but only a kind of know-how and traditional knowledge related to the fact and nature of these issues. The lack of such traditional techniques was assigned in more than a place to the control of the top-down approach on the conservation policy-formulation, which in turn ascribes the task to those specialists, condoning the 'policy community' who is the local community (Jordan 1990: 327).

An example of this is represented by a renovation process conducted on Erbil Citadel heritage site, which 'is an ancient city built on top of an artificial mound raised up by the successive rebuilding of houses and other structures on top of each other over thousands of years' (Huszar 2009: 67) (Figure 2). The renovation, which is a paradigm of a purely top-down approach of conservation decision-making process, mirrored a state of controversy regarding its novelty and to what extent it touches or emanates from the site privacy. Some findings indicated by the Final Report on the site (2009) reveal that a series of urban and architectural changes undertaken by the renovation decision-makers was made as if it was 'deliberate demolitions' on the site, such as the decision of 'the demolition of the historical gate' (p. 68). As a result, some serious outcomes have affected the physical integrity, cultural values and historical authenticity of the gate, as explicit evidence to that shows the renovation negates if not cancels the traditional architectural values of the site (HCECR 2012). 
Figure 2. "Left": The Citadel In 1951, Before The Renovation; "Right": The Citadel After Renovation

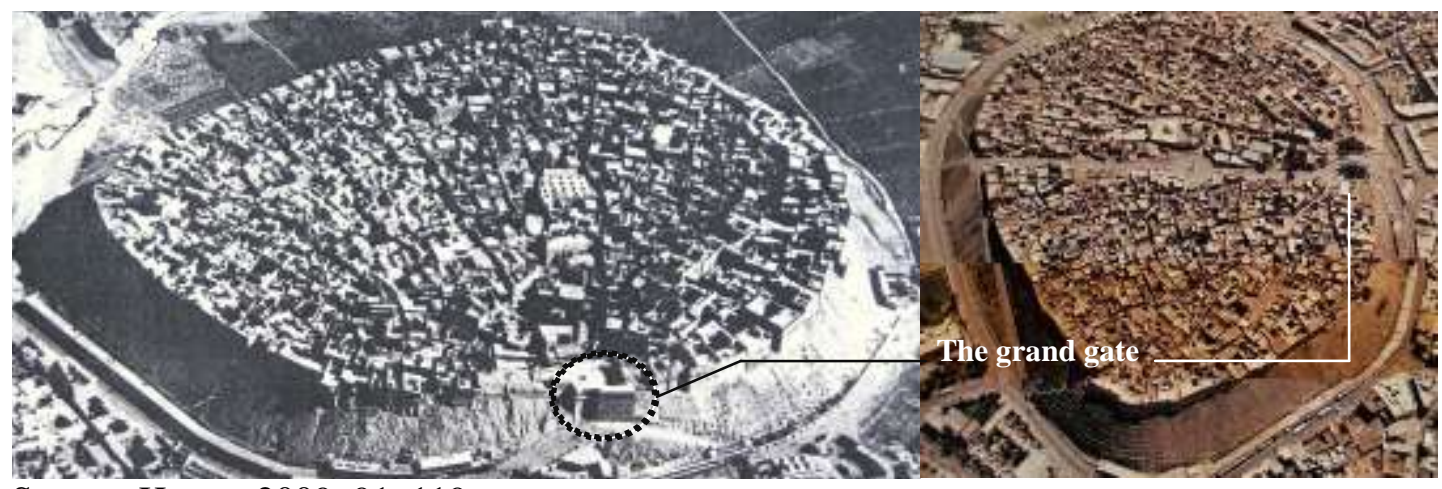

Source: Huszar 2009: 91, 119

Hence, dealing with conservation as a one-way decision-making process is not the solution. Empowering the decision-makers to act as all knowing sometimes impacts negatively on the site, particularly if this site is an amalgamation of diverse historical events and different ancient sociocultural values. In such a case, an optimal solution might be through celebrating the local community's experience of the site. The inhabitants represent 'a stable network which has advantages in encouraging bargaining in policy resolution' who sets 'effective shared views...on the problem' (Jordan 1990: 327). Therefore, their active participation may support the conservation decisions to be strongly attached to the site.

Controlling the conservation process by the top-down approach confronts a challenge in how to preserve the heritage site integrity, and simultaneously cannot effectively boost the site's intangible dimensions without compromising its values. It is a task, which heritage policies should always grapple with. This finding is what the (Contemporary Theory of Conservation) has come to dually emphasise, which leads to different drawbacks and in the foreground is a noticeable absence in the local community role. The power of the local participation affords a balance in the mechanism of tackling these issues equally with the site's decision-makers. Therefore, as a solution against the one-direction decision-making process, Blandford (2007) recommends involving the inhabitants in neutral drafting of the policy and its aims that entails an actual identification of their views and interests, considering them as a key-site issue. Accordingly, a new approach to a resilient strategy that ensures the rightful participation for all parties in the conservation decision-making should be activated.

\section{Decentralising Power as an Optimal Strategy in Drawing Heritage Conservation-policy}

Based on the recommendations of The World Conservation Union in (2004), sharing authority should receive a genuine priority from the different parties of the site in order to 'share information, advice and conservation benefits with 
the concerned communities. Empower [them] to participate in, [and] engage the $[\mathrm{m}]$ in negotiation process' (p. iv). Therefore, the most appropriate mechanism of planning for compatible cultural heritage policies is perhaps to submit to what the current study extracted as a decentralised power strategy, which is based on co-decision methodology between the site's authority and inhabitants. This approach offers 'a continuous problem-solving process, rather than a fixed state, involving...negotiation within problem-solving networks', which guarantees 'power sharing between the State and a community of [the site]' (Carlsson and Berkes 2005: 65). It therefore decentralises the whole process of the policy's decision-making, which consequently enfolds the priorities of the site as a kind of shared rights and duties between the authority and the local community.

Decentralising the decision-making process of the conservation policies entails numerous ends, such as:

1. The Dynamic Participation of Purposeful Concepts: according to Carlsson and Berkes (2005), it enables the formulating of 'adaptable and flexible [policies] through the use of multiple perspectives and a broad range of...knowledge and understanding, including those of [the local] communities' (p. 67). This approach facilitates the exchange of a wide base of cultural information that later add to the reinforcement of the site's future policies. The mutual role between these two main powers, the site's authority and inhabitants, is relative so that increasing, if required, the role of one of them will always be at the expense of the other and based on the site's requirements (Figure 3).

Figure 3. Changeable Level of Interaction between 'A' "Authority" and ' "Inhabitants" Governed by the Site's Requirements and Consequently The Decision Inputs of the Conservation; Source: The Researcher

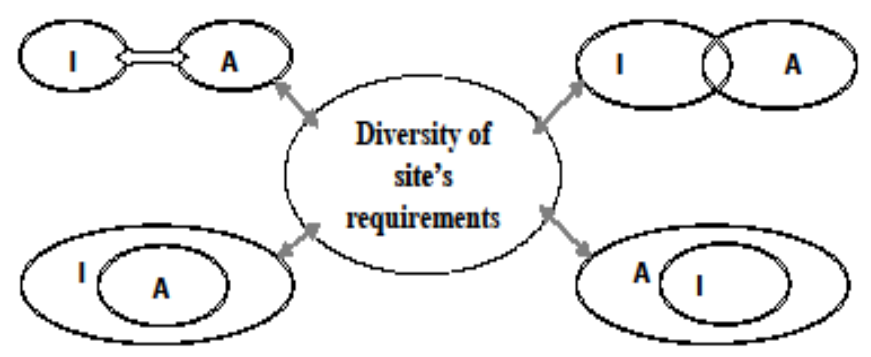

2. Conflicts Control: as long as the local community effectively participates in the formulation of the conservation polices, many of the conflicts around the site can be controlled due to the pre-codification of the responsibilities and priorities of the participating parties (Ostrom 1990). In fact, this underscores the role of the inhabitants as a 'policy community', who demonstrate 'effective shared views...on the problem' (Jordan 1990: 327). Here, the residents' opinions should be activated at the stage of collective decisions of the policy and prioritised as a meaningful contribution as a 'future right to be exercised' upon the site (Carlsson and Berkes 2005: 70). Thus, it is more 'society-centred... manifested in different types of networks and partnerships' (Pierre and Peters 
2000: 3), which authorises the local community to boost its status against the authority's domination on conservation policy formulation.

In this regard, granting the locals a kind of authority for planning for the site will ultimately promote heritage management towards wider comprehensiveness, embedding a spectrum of social, urban and cultural needs (McCay and Jentoft 1998). In contrast, reducing the local participation and confining the policymaking only to the top-down decision makers has been considered an escalation for the situation of built heritage as a "source of conflict" that may negatively influence its future destination.

3. Establishing a Level of Equality: sharing power in this regard does not necessitate eliminating power relations among the different parties of the site authority. Simultaneously, it serves the site residents in gaining a level of equality through the new synthesis of political and social components. This enables expediting more objective data gathering and a more targeted plan. Sharing the responsibility of the site assists in confronting some fundamental challenges, which often accompany any heritage conservation, such as strengthening the cultural identity of those indigenous as well as securing their rights and duties towards the future of the site. Above all, it guarantees the inscription of some crucial legislations that aid the local community's involvement (IUCN 2004); which ensures a mutual interest shared between the site's power and inhabitants (Beltran 2000).

Castro and Nielsen (2001) suggest further role for the locals through insisting on enrolling them equitably with the site power and the state agencies in a real co-management of the conservation process, which would grant substantial promise for the heritage diverse policies. Both argue that 'strengthening of the state's control over [heritage] policy...instead of contributing to local empowerment...may further marginalise communities' in supporting heritage performance (p. 229). The community participation in the re-manufacture of built heritage is 'crucial not only for social change but also for the continuous creation of [heritage values] by society itself' (Castro and Nielsen 2001: 229).

4. A more Comprehensive Process of Decision-making: it allows for the diversity of various capacities and comparative merits premised on 'the different kinds of skills and knowledge' provided by exchanging the decision inputs and outputs through a two-way mechanism (Carlsson and Berkes 2005: 71). It facilitates mapping and pursuing the policy through a bottom-up critique and top-down revision (Figure 4). Consequently, it suggests more rational protection for the architectural features of the site from the environmental deterioration as well as being well-clarified far-reaching planning for the built heritage. 
Figure 4. Heritage Site's Formal Agencies and Communities' Participation in Policy-making Process

\begin{tabular}{lll}
$\begin{array}{l}\text { Top-down policy: } \\
\text { full responsibility } \\
\text { held by the site's } \\
\text { decision-makers }\end{array}$ & $\begin{array}{l}\text { Decentralised/shared } \\
\text { power of heritage site: } \\
\text { shared responsibilities } \\
\text { between the site's } \\
\text { decision-makers and } \\
\text { inhabitants }\end{array}$ & $\begin{array}{l}\text { Bottom-up policy: } \\
\text { full responsibility } \\
\text { held by the site's } \\
\text { inhabitants }\end{array}$ \\
$\begin{array}{l}\text { Seek consensus through } \\
\text { consultation concerning } \\
\text { the site issues via sharing } \\
\text { benefits, socially and } \\
\text { economically }\end{array}$ & $\begin{array}{l}\text { Mutual negotiations: } \\
\text { involving the inhabitants } \\
\text { and the decision-makers to } \\
\text { develop unified policies }\end{array}$ & $\begin{array}{l}\text { Prioritise: the site } \\
\text { inhabitants with actual } \\
\text { responsibility in the } \\
\text { drawing up of the } \\
\text { conservation policies }\end{array}$ \\
\hline
\end{tabular}

Source: modified from (Carlsson and Berkes, 2005)

Central to the creation of such objective policies, the Australia ICOMOS (1998), dictates the co-responsibility of local communities together with the site authority, which ensures an objective assessment of the cultural significance of the built heritage. This is due to being the elite who have an inherent and 'ancient possession, continuity of relationship, historical ties, cultural ties and direct dependency' of the site (IUCN 2004). They are thereby worthy "co-management partners" for making heritage decisions and structuring policies.

As a result, the significance of locals' participation in formulating heritage conservation policies and making its cultural and tourist decisions can be attributed to:

I. The complementary relationship between the site inhabitants and their legacy, which grants thorough narrative stories regarding the site's diverse cultural values and events.

II. Sharing a wide range of mutual social meanings and historical memories of some particular experiences of the site.

III. The site inhabitants are interlinked as a part of a heritage network with power inherently entrenched in the site throughout its history.

IV. The collective image of the local community towards the dilemmas surrounding built heritage assists in dismantling and analysing their causes and effects, besides presenting a comprehensive site description with regard to its vague issues.

V. The ancient coexistence between the inhabitants and the site assists in drawing up functional and inexpensive policies.

VI. Culturally, the collective agreement among the audience with respect to the priority among these values enables valorising consequently tailoring some of the site's outstanding values within the formulation of the heritage policies.

VII. They are the elite who have inherent possession and consistent cultural relationship with the site. 
VIII. Touristically, the public is a viable tool for bringing into being a stock of cultural events of the patrimony, converting the site into a panoramic screen of cultural meanings for the visitor, reflecting the dynamics of heritage in presenting history.

IX. The local residents sift the authentic image of the built heritage regarding its pristine social traditions and original cultural identity that increases the site transparency thereby enhancing the assessment of the site's touristic profile.

\section{Findings and Discussion}

Despite the global emphasis on the actual engagement of local communities in heritage conservation policies, their local participatory role still lacks real activation in many world heritage sites. Different causes underlie that, which may demand more debate, as:

- Firstly: the intense reliance by the local authorities of these sites on the global experts and the stipulated charters as supreme criteria. In fact, although the study is almost conclusive with this fact, it cannot be ascertained that these criteria can work as a lasting source, which offer permanent solutions concerning the heritage cultural, historical and tourist issues. Thereby, they should not be given an absolute primacy in the process of conservation policy-making on the expense of the actual users of the site, who are the local communities. This might be the dilemma of many of these sites. In fact, the opinions of the heritage scholars should not be taken as articles of faith over the locals' views. Contrariwise, heritage decisions should be recognised as complex negotiations whereby diverse parties bring their own ideas, which can be merged and dissolved together (Avrami et al. 2000). The locals' opinions should compose a substantial component of these complex negotiations, as they often emanate from the core of the site and should act as a vital supporter in caring for heritage and its decisions' formulation. The inhabitants usually place upon the site's architectural elements a set of cultural values that subsequently acquire their collective acceptance to become the guiding criterion as "value-led conservation" that culturally heritage decisions are premised on (Vinas 2005).

This perhaps demands a revision of some heritage global charters, and embedding them new articles and clear criteria that secure a permanent activation for the local views towards heritage's historical and cultural issues. Re-viewing these charters in order to re-embed some procedures that may balance the audience's contributions with those of heritage specialists might represent an appropriate approach for valid decisions regarding the future of built heritage, culturally and touristically. Centralising the task of conservation policies on the role of the site's experts only would might lead either to globalising the process 
or to trivialising the local participatory role (Avrami et al. 2000, Staniforth and Griffin 2000).

To be neutral, these "articles of faith" also carry positive aspects for guaranteeing an objective policy-formulation concerning reducing the intervention of the local authorities. They work on protecting the site from the rampant propagation of the domination of local authorities upon the conservation decision-making process of some local bureaucratic systems. The latter mostly besieges conservation policies by the political authority, which consequently offers a granted power for the site's decision-makers to constitute the site policies through a one-direction policy, which often aims at supporting some tourist goals that does not necessarily emanate from the site's true values. As a result, guiding heritage conservation by global experts does not necessitate the abolishment of the bottom-up views but rather endeavours to establish an applicable conservation policy, which involves both the specialists and the inhabitants.

- Secondly: though some global heritage sites recently have witnessed increasing calls, appealing at exploiting their local communities as local supporters, still the local authorities impede these social elite from efficient engagement. Given the diagnosis of some concerns that perhaps results from the locals' participation, some local authorities still question the role that the public can exactly play in formulating the heritage policies. In some cases, the indigenous inhabitants' hardness in accepting some unprecedented concepts and innovative techniques may represent impasse on decision-making processes. In addition, their excessive interpretation of the heritage values, which instead of framing their criticality, may decrease the clarity of the policies (Aas et al. 2005, Su and Li 2012). Here, the most appropriated technique to benefit from the local interpretations might be through setting a predetermined trajectories for the locals through which their views can be guided to maintain them tied to a particular issue within the site. Furthermore, showing the inhabitants how some global techniques of conservation can be localised through some actual conservation experiences would also facilitate some positive responses towards them locally. Consequently, it helps to maintain these techniques "innovative" but with regard to the particular issues of the site.

- Thirdly: the mutual role in the conservation policies' formulation, represented by the authority, the official parties, and the role of the global experts as well as the local community shows a case of inconsistency. The latter may escalate the situation in how to planning for the site that subsequently leads to creating conflict mostly centres on the economic potentials behind the diverse cultural values of the heritage. As a consequence, it holds some difficulties regarding coordinating the priorities and responsibilities of each party which increases the intricacy of the site management structure ( $\mathrm{Su}$ and $\mathrm{Li} 2012$ ). This perhaps results in some confusion in how to balance between the responsibilities of 
these two main powers, the site's authority and audience. Consequently, to overcome this dilemma and achieve an efficient conservation policy, Mimi et al. (2008), and Su and $\mathrm{Li}$ (2012) argue that a clear connection between the site's management structure and its inter-relationships among its decision-makers and inhabitants is essential, which what the study robustly emphasises here.

- Fourthly: the vague relationship between the site's authority and individuals still downgrades the local participatory role in formulating heritage policies (Hughes and Pupavac 2006, Causevic 2011, Huang et al. 2012). From a perspective of authority, the locals' subjective narratives, which are difficult to be objectively assessed, may destabilise the significance of heritage values, which may lead to an uncritical assessment regarding four prime issues. Firstly, balancing between the standing of the site locally and globally as well as evaluating the variance of the site value according to the diversity of its tangible features, in addition to the different interrelated cultural values, and finally their representativeness. As a result, it may be hard to draw critical policies through mainly relying on their contributions (Dicks 2000, UNESCO 2005, Poria and Biran 2006, Thapa 2007). However, what might be suggested here to objectively motivate these contributions is to enlighten the locals of more knowledge about the global significance of their heritage. Besides being integral to their residents' local cultural identity, heritage sites are also part of the place identity on a global scale. If this sense is highly fostered among the inhabitants, it can contribute in upgrading their understanding of the site's cultural value, and thus give more objective reading of its tangible and intangible features. This boosts the acceptance of the locals' contributions among the site's decision-makers, consequently reinforces their participatory role in making heritage policies.

Another controversy is also identified between the site's authority and inhabitants, which concerns the inclusion of the site into the World Heritage List 'WHL' and the potential change that may have on the site. Two basic visions can be raised regarding that, referring to some economic and physical aspects of the site.

- Economically: given the substantial influence upon heritage tourism by this inclusion, the authority strives to stimulate an active policy of tourismled growth through inscribing the site into the 'WHL' so as to assess and motivate the viability of the built heritage (Huang et al. 2012). Particularly, as soon as the anonymous site becomes known after being listed on the 'WHL', it will begin to be visited noticeably by international tourists ( $\mathrm{Su}$ and Lin 2014). This inclusion robustly boosts the positive impacts through multiple means, such as the tourist economic development, and the natural resources and cultural achievements of a sustainable conservation (Mimi et al. 2008, Huang et al. 2012). Additionally, UNESCO will take into account its full responsibility of the heritage site in terms of providing financial 
and technical support for the site immediately after being inscribed on the 'WHL'. Supposedly, such advantages should induce the authority to work on such inclusion.

- Physically and more: despite the affirmation that 'WHL' focuses on identifying and protecting the outstanding cultural values of the site, the local concerns are based on some heritage scholars' attitudes with regard to the site integrity and how to establish an intact methodology, preventing the site from loaded visits that might result in unexpected deteriorations (Yang and Yu 2004, Yang et al. 2010, Huang et al. 2012). Yet, granting these local concerns real consideration through emphasising the site integrity and scheduling the site visits would support the policies rather than weakening them. As a result, the critique of the inhabitants regarding the inclusion of the site into the 'WHL' warns from unexpected deterioration of the site, which should be appreciated here.

\section{Conclusion}

The local community of the heritage site should be equitably engaged with the site authority, the local and global experts and the international charters as an interrelated network when drafting any decision related to the site conservation. Though they are unauthorised to draw up a specific decision individually, they are eligible to participate in the conservation's decision-making process of their "home". The conservator's work has, of course, expert-only aspects, but it also has many aspects in which no technical knowledge is involved. For instance, feelings, sentiments, memories, preferences and interests are the key factor to be considered. Taking into account the opinions of non-experts implies that the "experts-only zone" becomes an "affected-people zone", and the process of conservation, (which supposed to be an "experts-only zone" and depends on increasing the role of the authority of the experts' realm), will be with "open ends". This open-ended process will allow for any potential participation by the inhabitants. Their equitable participation perhaps assists in consolidating new decisions or delaying the unavoidable decay of certain heritage, as a part or a whole, which is the core of the conservation process.

More emphasis should be placed upon the importance of pluralism in drawing up heritage policies, which should become "the starting point" or the "ground" for heritage futuristic policies (Castro and Nielsen 2001). This would enable the balancing of traditional with modern techniques while drawing up these policies, as it incorporates local practices and skills into the experts' zone of heritage for a fundamental reason: the site inhabitants contribute valid and genuine knowledge that assists in detecting 'collective-action problems' concerning different issues, interests and concerns about the site (Castro and Nielsen 2001: 237). Their broad-based knowledge allows the local communities to 'empower these institutions instead of subverting them' (Holm et al. 2000: 353), as real equal partners of rightful priorities that qualify them to efficient participation. 
Some of the conservation experiences, such as the renovation of Erbil Citadel, bring to the surface an enigmatic fact that the gap of local participation role in most of these experiences is perhaps premised on the shortage of the emphasis on this role within their local conservation laws. This might be attributed to the circumstances that surround the mechanism of law formulation, which is restricted by the local political authority and the site decision-makers. Both often impose their control upon the conservation decisions and policies, which reciprocally marginalises the role of the local community. More precisely, the decentralised power strategy for sharing the responsibility of policy formulation with the site inhabitants is completely ignored in such experiences, making the objective assessment of the local conservation policies far from transparency, which requires reinvestigation.

\section{References}

Aas C, Ladkin A, Fletcher J (2005) Stakeholder Collaboration and Heritage Management. Annals of Tourism Research 32(1): 28-48.

Avrami E, Mason R, Torre M (2000) Values and Heritage Conservation: research Report. Los Angeles: The Getty Conservation Institute.

Beltran JE (2000) Indigenous and Traditional Peoples and Protected Areas: Principles, Guidelines and Case Studies. IUCN, Gland, Switzerland and Cambridge, UK and WWF International, Gland, Switzerland.

Blandford C (2007) Management Plans for UK World Heritage Sites: Evolution, Lessons and Good Practice. Landscape Research 31: 355-362.

Byrd E (2007) Stakeholders in Sustainable Tourism Development and their Roles: Applying Stakeholder Theory to Sustainable Tourism Develoment. Tourism Review 62(2): 6-13.

Carlsson F, Berkes F (2005) Co-management: Concepts and Methodological Implications. Journal of Environmental Management 75: 65-76.

Casey E (2007) Boundary, Place and Event in the Spatiality of the History. Rethiniking History 11: 507-512.

Castro A P, Nielsen E (2001) Indigenous People and Co-management: Implications for Conflict Management. Environment Science 4: 229-239.

Causevic S (2011) Phoenix Tourism: Post-Conflict Tourism Role. Annals of Tourism Research 38: 780-800.

Chapman E (2008) Community, Heritage, Identity: Constructing, Performing and Consuming Welsh Identities in the US.

Cochrane J, Tapper R (2006) Tourism's Contribution to World Heritage Sites Management. In Managing World Heritage Sites. Burlignton: Elsiver Ltd.

Crooke E (2007) Museums, Communities and the Politics of Heitage Northern Ireland; In Museums in their Communities. London: Routledge.

Dicks B (2000) Heritage, Place and Community. Cardiff: University of Wales Press.

Dicks B (2003) Culture on Display: The Production of Contemporary Visibility, Maidenhead. Berks: Open University Press.

Feilden BM (1998) Management Guidelines for World Cultural Heritage Sites (Rome: ICCROM).

Hall C (1999) Rethinking Collaboration and Partnership: A Public Policy Perspective. Journal of Sustainable Tourism 7: 274-289. 
Hall C (2000) Tourism Planning Process and Relationships, Harlow: Prentice Hall.

Hall C, Mcarthur S (1998) Integrated Heritage Management, London: Stationary Office.

Hampton M P (2005) Heritage, Local Communities and Economic Development. Annals of Tourism Research 32(3): 735-759.

HCECR (2012) Highlights of ErbilCitadel: History and Architecture: Visitor Guide.

Hidaka LCF (2008) Contemporary Theory of Conservation, by Salvador Munas Vinas. City \& Time 4(1).

Holm P, Hersoug B, Ranes SA (2000) Revisiting Lofoten: Co-managing Fish Stocks or Fishing Space? Human Organisation 59 (3): 353-364.

Huang C, Jen R, Yang C (2012) Does World Heritage List Really Induce More Tourists? Evidence from Macau. Tourism Management 33: 1450-1457.

Huang YL (2006) Research on Residents' Attitude and Perceptions on Tourism Impacts at Chinese World Heritage Sites: A Case Study of Pingyao Ancient City. Journal of Guilin Institute of Tourism 17: 124-127.

Hughes C, Pupavac V (2006) Framing Post-conflict Sociesties: International Pathologisation of Cambodia and the Post-Yugoslav States. Third World Quarterly 26: 873-889.

Huszar B (2009) Revitalisation of Erbil Citadel-Iraq-Phase I. Final Report: Summary of Activities and Outputs of the Project.

ICOMOS (1964) International Charter for the Conservation and Restoration of Monuments and Sites (The Venice Charter 1964).

ICOMOS (1998) Code on the Ethics of Co-existence in Conserving Significant Places; adopted by the Australia ICOMOS 1998.

ICOMOS (1999) The Burra Charter :The Australia ICOMOS Charter for Places of Cultural Significance.

ICOMOS (2002) Principles and Guidelines for Managing Tourism at Places of Cultural Heritage Significance.

ICOMOS (2004) Principles for the Conservation of Heritage Sites in China. The Getty Conservation Institute.

ICOMOS (2008) Quebec Declaration on the Preservation of the Spirit of the Place. Adopted at Quebec, Canada.

ICOMOS (2013a) The Burra Charter: The Australia ICOMOS Charter for Places of Cultural Significance, 2013.

ICOMOS (2013b) Understanding and Assessing Cultural Significance, Practice Note, Version 1, Australia ICOMOS

IUCN (1996) World Conservation: Special Issue on Collaboration Management, No. 2.

IUCN (2000) Indigenous and Traditional Peoples and Protected Areas: Principles, Guidelines and Case Studies. In: Beltran E. A. C. B. J. (ed.) Best Practice Protected Area Guidelines Series No. 4. World Commission on Protected Areas (WCPA).

IUCN (2004) Indigenous and Local Communities and Protected Areas: Towards Equity and Enhanced Conservation, Guidance on Policy and Practices for Co-managed Protected Areas and Community Conserved Areas, Grazia Borrini-FFeyerabend, Ashish Kothari and Gonzalo Oviedo, with inputs from Marco Bassi, Peter Bille Larsen, Maurizio Farhan Ferrari, Diane Pansky and Neema Pathak. In: World Commission on Protected Areas (WCPA).

Jackson JB (1983) The Necessity for Ruins and other Topics. Amherst: University of Massachusetts Press.

Jenkins-Smith HC, Sabatier PA (1993) The Study of the Policy Process. Boudler: Westview Press.

Jiang TT (2006) TajMahal and the Great Wall: A Comparative analysis of Sino-Indian World Heritage Protection. South Asia Research Quarterly 1: 90-93. 
Joppe M (1996) Sustainable Community Tourism Development Revisited. Tourism Management 17: 475-479.

Jordan G (1990) Sub-governments, Policy Communities and Networks, refilling Old Bottles? Journal of Theoretical Politics 2(3): 319-332.

Kerr JS (2013) Conservation Plan: A guide to the preparation of Conservation Plans for Places of Europe Cultural Significance, $7^{\text {th }}$ ed.

Lowenthal D (1985) The Past is a Foreign Country. Cambridge: Cambridge University Press.

Macdonald R, Jolliffe L (2003) Cultural Rural Tourism: Evidence from Canada. Annals of Tourism Research 30: 307-322.

Mccay BJ, Jentoft S (1998) Market or Community Failure? Critical Perspectives on Common Property Research. Human Organisation 1: 21-29.

Mckercher B, Ho P, Ducros H (2005) Relationship between Tourism and Cultural Heritage Management: Evidence from Hongkong. Tourism Management 26: 539548.

Mimi LB, Wub, Liping C (2008) Tourism development of World Heritage Sites in China: A Geographic Perspective. Tourism Management 29: 308-319.

Mitchell R, Reid D (2001) Community Integration: Island Tourism in Peru. Annals of Tourism Research In Phenomenology 28: 113-139.

Nicholas LN (2009) Residents' Perspectives of a World Heritage Site. Annals of Tourism Research 36: 390-412.

Nuryanti W (1996) Heritage and Postmodern Tourism. Annals of Tourism Research 23: 249-260.

Ostrom E (1990) Governing the Commons, New York: Cambridge University Press.

Pierre J, Peters G (2000) Governance, Politics and the State. Macmillan: Basingstoke.

Poria Y, Biran A (2006) Heritage Site Management: Motivations and Expectations. Annals of Tourism Research 33 (1): 162-178.

Poria Y, Butler R, Airey D (2003) The Core of Heritage Tourism. Annals of tourism research 30(1): 238-254.

Roberts L, Simpson F (1999) Developing Partnership Approaches to Tourism in Central and Eastern Europe. Journal of Sustainable Tourism 7: 314-330.

Silva K, Chapagain N (2013) Asian Heritage Management: Contexts, Concerns, and Prospects. Oxon: Routledge.

Staniforth S, Griffin I (2000). Damp problems in the Chapel at Cliveden. The conservation of heritage interiors: preprints of a conference symposium, 17-20 My 2000, Ottawa, Canada, 177-184.

Su M, Li B (2012) Resource Management at World Heritage Sites in China. Procedia Environmental Sciences 12: 293-297.

Su Y, Lin H (2014) Analysis of International Tourist Arrivals Worldwide: The Role of World Heritage Sites. Tourism Management 40: 46-58.

Taylor K (2004) Cultural Heritage Management: A Possible Role for Charters and Principles in Asia. International Journal of Heritage Studies 10: 417-433.

Thapa B (2007) Issues and Challenges of World Heritage Sites in Nepal. In World Heritage: Global Challenges and Local Sollutions. Oxford: Archaeopress.

Timothy D (1999) Participatory Planning: A View of Tourism in Indonesia. Annals of Tourism Research 26: 371-391.

TIMOTHY DJ, BOYD S W (2003) Heritage Tourism, Harlow. UK: Prentice Hall.

Tunbridge J, Ashworth GJ (1996) Dissonant Heritage: The management of the Past as a Resource in Conflict, Chichester. UK: Wiley.

UNESCO (2005) Operational Guidelines for the Implementation of the World Heritage Convention. Paris: UNESCO World Heritage Centre. 
UNESCO (2013) "Engaging Local Communities in the Stewardship of World Heritage". Retrieved from http://bit.ly/2BlVjri.

Uriely N, Israeli A, Reichel A (2003) Religious Identity and Residents' Attitudes toward Heritage Tourism Development: the Case of Nazareth Heritage. Journal of Hospitality \& Tourism Research 27 (1): 69-84.

Vinas SM (2005) Contemporary Theory of Conservation. Oxford: Elsevier.

WAAC (1996) AIC Definitions of Conservation Terminology. Etrieved from http:// cool.conservation-us.org/waac/wn/wn18/wn18-2/wn18-202.html.

Wager J (1995) Developing a Strategy for the Angkor World Heritage Site. Tourism Management 16: 515-523.

Wan KF (2004) Tourism Policy Making at World Heritage Sites in China. Guangxi Social Sciences 9: 75-77.

Yang C, Lin H, Han C (2010) Analysis of International Tourist Arrivals in China: The Role of World Heritage Sites. Tourism Management 31(6): 827-837.

Yang L, Yu X (2004) A Summary of China's Researches on the Protection and Utilisation of Cultural Heritage. Tourism Tribune, 85-91.

ZhanG S (2006) Reflections on Wannan Ancient Village Development and Tourism: A Case Study of World Heritage Site of Hongcun Village. Journal of the Party College of C.P.C. Hefei Municipal Committee 3: 50-52. 